admit the same formal treatment it follows that, so far as the mathematics goes, there can be nothing in one which is not implicit in the other. But familiar models of less familiar phenomena have at least one advantage. They make it easier to distinguish between intrinsic features of the phenomenon, and others which are introduced by the method of analysis. One might be inclined to think that sharply defined states, characterized by integral numbers, are peculiar to quantum phenomena, or at least that they require special mechanisms to imitate them classically, such as strings or membranes. But we have seen that in the acoustical model the integers emerge as a part of the mathematical background before any physical phenomenon has appeared on the stage. The ultimate reason for the emergence of 'acoustical quanta' is that we have viewed the same phenomenon simultaneously from two different aspects, and described it by two 'quantities of interest', time and frequency. Any number of other classical models may be found, if only we ask simultaneously two kinds of questions about the same thing, or perform two lines of experiments on it, provided that the questions are neither identical nor independent.

'Landé, A., "Vorlesungen über Wellenmechanik"' (Leipzig, 1930).

'Gabor, D., J. Inst. Elect. Eng., Part III, 93, 429 (1946).

${ }^{3}$ Potter, R. K., Science (Nov. 9, 1945). Koenig, W., Dunn, H. K., and Lacy, L. J., J. Acoust.' Soc. Amer., 18, 19 (1946).

' Bürck, W., Kotowski, P., and Lichte, H., Elek. Nachrtech., 12, 326 (1935); 12, 355 (1935).

' Shower, E. G., and Biddulph, R., J. Acoust. Soc. Amer., 3, 274 (1931).

- Wegel, R. L., and Lane, C. E., Phys. Rev., 23, 266 (1924). 'Galambos, R., and Davis, H., J. Neurophysiol., 6, 39 (1943) ; 7,
285 (1944).

\section{A CHEMICAL BICENTENARY AT THE UNIVERSITY OF GLASGOW}

\author{
By Dr. ANDREW KENT \\ Department of Chemistry, University of Glasgow
}

A RISTOTELIAN physics and astronomy had had place in the arts curriculum at the College of Glasgow ever since King Jamie wi' the Fiery Face welcomed the advent of Scotland's second University (1451). In the eighteenth century a more modern science was recognized by the institution of chairs in natural philosophy (1717) and practical astronomy (1760).

Between these events in the Faculty of Arts, William Cullen completed the first course of lectures in chemistry (1747). This lectureship in the Faculty of Medicine was part of a renewed and finally successful effort to provide his Alma Mater with the prestige of a comprehensive medical school, the steady expansions of whieh included the later regius chair of chemistry (1818).

Cullen was perhaps the greatest physician to teach chemistry in this or any other British university. Although there is some evidence that he would have preferred to place the subject in the wider field of arts, there was, of course, nothing unusual in its association with eighteenth-century medicine. The notable factors are the broad and enlightened views which this polymathic personality adopted in the scope and emphasis of his teaching, and his lasting influence on the new department.

During 1747-1874 the Department was headed, for all but three years, by professional physicians.
Although the degree of B.Sc. was first conferred in 1873, and the belated Faculty of Science (1893) included lectureships in organic chemistry (1898), in metallurgical chemistry (1899) and in "Physical Chemistry including Radio-activity" (1904), the chair of chemistry was first detuiled in the calendar under 'Faculty of Science' only in 1920. Although even the nineteenth-century class of 'Practical Chemistry' pursued a course of "bases and acids, poisons and the pharmaceutical compounds", there was always a group of 'laymen' in the principal class of systematic chemistry and in the laboratory. For these freedoms of outlook and emphasis a lasting gratitude is due to William Cullen.

So the portentous association of Joseph Black (1756) with James Watt has its place in world history. John Robison (1766) was not a physician. William Irvine (1769) and T. C. Hope (1787) were physicists of note. Robert Cleghorn (1791) may have concentrated unduly on his duties to the students of medicine; but with Thomas Thomson (1817), the first regius professor, the lectures certainly reverted to a wider scope, which was undiminished during the tenure of his successor, Thomas Anderson (1852). With the advent of John Ferguson (1874) the medical dynasty is at an end : the now legendary 'Soda' took an active part in framing the new Faculty of Science, and in completing a near century of service by the first three regius professors. The fourth, G. G. Henderson (1919), guided the Department to its present Faculty. 'The 'auld alliance' has since been represented by a lecturer in 'Chemistry for students of Medicine' and by the research interests of George Barger (1937) and of James W. Cook (1939). In the Gardiner chair T. S. Patterson (1919) and J. Monteath Robertson (1942) have emphasized the modern significance of organic and of physical chemistry.

These heads of department, six of whom were products of the chemistry class, have seen their opportunities grow fiftyfold since some twenty students first gathered around Cullen. Since 1861 they have enjoyed the support of official colleagues such as, among others, William Ramsay, J. J. Dobbie, Frederick Soddy and C. H. Desch. The present teaching and research staff, some thirty strong, installed in a new and well-equipped building, have also behind them two hundred years of provocative tradition.

The Department has not only carried out its natal responsibilities in the teaching of medicine. It has helped to fashion in earlier days physician-scientists like Joseph Black, John MacLean of Princeton, and Thomas Graham, professional scientific workers like John Robison, William Thomson (Lord Kelvin) and (Sir) William Ramsay, entrepreneurs like Charles Macintosh and William Couper.

The Duke of Hamilton, descendant of Cullen's friend and patron, will preside over the first of a bicentenary series of lectures to be given this month by Dr. Douglas Guthrie, Prof. John Read, Dr. Alexander Fleck and Prof. A. R. Todd. Later, it is intended to publish a commemorative volume, edited by the present writer, in which scientific men of diverse interests and of many colleges will combine in tribute to those early pioneers whose far-sighted ambitions have eventuated in the multifold activities and the wide influence of the school of chemistry at the University of Glasgow.

The careless dust of time has overlaid some points of interest. It is not easy now to discover the type of chemistry taught by Cleghorn during a tenure of 
the lectureship (1791-1817) which included many exciting advances in the subject; an era much given to portraiture and cartoon has left no traceable reproduction of the lineaments of William Irvine; memorialists have often concentrated on the various medical chairs which were held concurrently or successively by the lecturers in chemistry. Enough remains to afford a reasonable pride in associations with hermetic antiquity.

Lavoisier and Dalton were to find paladins in Hope and Thomas Thomson, but Boerhaave and Stahl were the first pedagogic exemplars. If alchemy were never countenanced, the 'Four Elements' and the Tria Prima were topics of critical discussion in the earliest lectures. From that point onwards the making of modern chemistry is mirrored in the teaching and researches of its exponents at Glasgow, and in the later activities of those thousands whose names have been enrolled in the class of chemistry since 1747.

\section{TAXONOMY OF AQUATIC INSECT NYMPHS AND LARVE}

\author{
BY DR. T. T. MACAN \\ Laboratory of the Freshwater Biological Association, \\ Wray Castle, Ambleside, Westmorland
}

\begin{abstract}
$\mathrm{A}$ LMOST any collection of freshwater animals will contain a high proportion of insects in the larval or nymphal stage, and a number of these cannot, at present, be named with certainty. The work of many biologists, whether their interest be in ecology, physiology or the food of fish, is affected by this gap in our knowledge, and the importance of closing it need not be stressed. It is the belief of the Freshwater Biological Association that, with sufficient co-opera. tion from workers in other parts of the country, it should be possible, within a few years, to produce keys for the identification of the aquatic stages of all the important groups, except the Diptera. The purpose of this article is to appeal for this co-operation, to which end it includes brief notes on the existing systematic literature of the various groups and a short account of some of the methods of rearing adults from their nymphs or larvæ.
\end{abstract}

It is hoped that some workers in other laboratories may be induced to turn their attention to systematic studies, and the Freshwater Biological Association is prepared to give all the assistance it can. Others may be able to help by breeding out the species occurring in their own neighbourhood and sending the material to Wray Castle to be described.

The Ephemeroptera and Odonata are under investigation at the moment at Wray Castle. The most urgent need is the description of those species at present not described in any language; but it is also desirable to redescribe and figure some of the species already known, as almost all the existing literature is based on Continental material and the illustrations do not conform to a uniformly high standard.

The Coleoptera and Hemiptera, which are aquatic throughout life, are considered of less importance at the present moment. The position of the other main orders with aquatic nymphs or larvæ is as follows:

Plecoptera. Hynes ${ }^{1}$ has described twenty-six out of the thirty-four probable British species, and two have been described since.
Ephemeroptera. Schoenemund's ${ }^{2}$ key to the German species includes thirty of the forty-seven British species. Descriptions of some of the remaining seventeen are scattered through the literature. The biggest gap is the genus Baëtis, common and widespread in Britain and an important element in almost any stream or river. There are nine British species, but the nymphs of only three have been described, and one of these is probably associated with the wrong adult.

Odonata. Lucas ${ }^{3}$ gives a key to the nymphs of all the British species, but experience at Wray Castle suggests that some of the species are distinguished on insufficient material, and the key does not always give the right answer. $\mathrm{May}^{4}$ states that sufficient information to make a key to the subfamily Agrioninæ or the genus Sympetrum is not available. The group clearly requires further study.

Trichoptera. The most complete key, that given by Rousseau ${ }^{5}$, is somewhat out of date. A revision of the larvæ of the group is being undertaken by Dr. N. E. Hickin, who has so far described some twenty of the British species (see Hickin ${ }^{6}$ for list of references).

Diptera. Complete keys to some of the smaller families, for example, Culicidæ ${ }^{7}$ and Simuliid $æ^{8}$ exist; others are among the least known of all the aquatic animals. The outstanding gap is the Chironomidæ, a very large family and one of great importance in freshwater biology. In spite of detailed work in Germany most larvæ can only be separated into species groups. Reference may be made to Goetghebuer and Lenz ${ }^{9}$. Separation into groups can also be effected by the use of Johannsen's ${ }^{10}$ keys, although this author is primarily concerned with the American fauna.

Many Ephemeroptera and Plecoptera live in flowing water which is always cool and well oxy. genated. Hynes ${ }^{1}$ describes a technique for rearing the nymphs which are collected in such places, and the apparatus is figured by Worthington ${ }^{11}$. Series of flat enamel dishes are placed on sloping shelves one below the other. Water entering the top dish of each series from a tap drips from one dish to another. Each dish is provided with stones for the nymphs to cling to and is covered with a sheet of mosquito netting on a wire frame. It is necessary to transfer newly emerged Ephemeroptera to a small tube for a day or two, in order to allow the imago to emerge from the sub-imago. Both nymphal skins and adults should be preserved in $2 \frac{1}{2}$ per cent formalin, the adults being first wetted in 70 per cent alcohol.

Stream-dwelling Ephemeroptera have, however, been reared in stagnant conditions where a supply of river water was immediately available. Useful collections have also been made by catching emerging sub-imagines in the field. A large collection of nymphs is made; those which, from their silvery appearance, are evidently about to emerge, are sorted into a dish, the collection is then watched, and each sub-imago is caught as it emerges.

Most Odonata inhabit stagnant waters and are easier to rear. They may be kept in pie dishes without running water, one nymph to a dish or they will devour one another. A stick or piece of reed should. be provided for the nymph to crawl up before emergence. Each dish should be covered by a cage, though, if this is not possible, and the dishes are in a room, of which the doors and windows can be kept closed, it is seldom that an adult is lost or cannot be associated with the skin from which it came. The 